\title{
PARTNERSÉG A MAGYAR FEJLESZTÉSI KONCEPCIÓK TERVEZÉSÉBEN
}

\author{
(Partnership in the Planning of the Hungarian Development \\ Conceptions)
}

\section{MOLNÁR BEÁTA}

Kulcsszavak:

parmerség tervezés fejlesżésikoncepció

Az Országos Fejlesztéspolitikai Koncepció és az Országos Terilletfejleszési Koncepció a második Nenzeti Fejlesztési Terv megalapozását (is) szolgálja. A dokumentumok elkészitésében számos partneer részt vett. a 2005 nyarán nyilvánosságra hozott cinyagok szcileskörï túrsadalmi egyeztetése ezt követöen közel egy hónapig tartott. A tanulmäny ezt a folyamatot, illetve annak tanulságait vizssálja.

\section{Bevezetés, uniós kitekintés}

1988-tól az EU regionális politikájának egyik alapelve a partnerség, ami a legkülönfélébb szereplök célorientált együttmüködését jelenti a közösségi forrásokat felhasználó fejlesztési programok kialakítása és megvalósítása során. (Horváth 2001; Lados-Rechnitzer 2004). A kooperáció nem csak azt teszi lehetővé, hogy az érintett felek információt szerezzenek, figyelembe vegyék az eltérő preferenciákat a tervezésben, hasznosítsák egymás tapasztalatait, hatékonyabbá, demokratikusabbá váljon a végrehajtás, hanem az is elérhető ăltala, hogy a különböző érdekekkel rendelkezö személyek, intézmények versengés helyett arra érezzenek motivációt, hogy közösen dolgozva legyenek minél eredményesebbek, vagyis maximalizálják a megszerezhető támogatásokat, azokkal hozzájáruljanak a régió felzárkózásăhoz, fejlődéséhez. Kezdetben (1988-1993) a partnerség az Európai Bizottság (EB) és a tagállamok közti kapcsolatokat takarta, késóbb azonban ez az elv kiterjedt a különbözö társadalmi - gazdasági szereplök bevonására ( $N$. Tóth $K .2005)$. Ezzel a résztvevők köre egyértelmüen kitágult pl. a szervezetek jellegét, területi elhelyezkedését stb. nézve. A partnerség megvalósítására vonatkozóan a közösségi rendeletek mindig csak keretjellegủ szabályozást tartalmaztak, a tagállamokra bízva a nekik leginkább megfelelő gyakorlat alkalmazását. Ez azért is helyénvaló, mert az egyes országok meglehetősen eltérőek a közjogi berendezkedést, területi beosztást, nemzeti regionảlis politikát, egyuittmúködési hagyomảnyokat illetóen (Horváth 2001). Bár az előbbiböl következóen a partnerség realizálása számos formát ölthet és különböző intenzitású lehet, az elv elfogadottsága okăn olyannyira beépült a tagállamok intézményrendszerébe, hogy mára túlmutat a Strukturális Alapok felhasználásán, tulajdonképpen általános követelménynek tekinthetö a kormányzásban. Elkülönül a partnerség 
vertikális és horizontális metszete, elöbbi az eltérő szinten lévő szereplök (EB, nemzeti kormányok, régiók, kisebb térségek, települések) együttmüködését takarja, utóbbi az azonos szintủ személyek, intézmények (területi államigazgatási szervek, önkormányzatok, érdekszövetségek, vállalkozások stb.) kooperációját jelenti. Fontosságát éppen az adja, hogy a politika szakít a hierarchikus, kizáró jellegủ megközelítéssel, és jóval tágabb kört kezel egyenrangú félként. (Ez persze nem egyenlö a felelösség vagy a feladatok azonosságával.) A partnerség elvét kapcsolatba hozhatjuk a szubszidiaritással, a decentralizációval, ami az alsóbb szintekre építkezést, az alacsonyabban, helyben történö problémamegoldást preferálja (felsőszintü koordináció mellett), de összefügg a tágan értelmezett nyilvánosság kérdésével is, mivel a tájékozódás, a véleményezés joga az egész civil szférára kiterjed (LadosRechnitzer 2004). (Az egyéb közremüködői teendőket már a kormány határozza meg egy szúkebb kör bevonásával.)

A programok menedzsmentje tehát a partnerség elvének betartásával alakul, a Strukturális Alapok általános szabályozását adó 1260/1999 EK rendelet és a 2007töl hatályos rendelettervezet e körben a következő szervezeteket említi:

- regionális és helyi hatóságok, állami szervek,

- gazdasági - szociális partnerek,

- egyéb illetékes szervek (civil, környezetvédő, nem-kormányzati, nöi-férfi esélyegyenlöségi szervezetek).

A rendeletek deklarálják, hogy a partnerségi elv betartása a teljes fejlesztési folyamatban érvényesül a tervezéstöl a finanszírozáson át (összefüggés az addícionalitás' elvével) a végrehajtásig, értékelésig. Ennél részletesebb szabályokat azonban a közösségi rendeletek nem tartalmaznak, így - a fent említettekre utalva végsô soron a tagállamok maguk alakítják ki a nekik leginkább megfelelő együttmüködést (szereplök, formák stb.).

Winkler (2004) tanulmányában a folyamat hat szakasza különíthetö el, ezekben a cselekmények - melyekbe a partnerek bevonhatók - az alábbiak:

- programkészítés: térségi és ágazati elemzések készítése, döntés a fố célokról, partnerekröl, az együttmüködés megalapozásal

- identifikáció: a fejlesztési ötletek és tevékenységek meghatározása, konzultáció a kedvezményezettekkel, problémák feltárása és megoldások keresése

- kidolgozás: a támogatott ötletek operatív programmá (OP) fejlesztése, a megvalósíthatóság biztosítása

- végrehajtás: a pályázatok meghirdetése utín a projektek kiválasztísa, döntés a finanszírozásról, szerződéskötés

- monitoring: a programok folyamatos nyomon követése, esetleges beavatkozás

- értékelés: az eredmények, célok teljesülésének felmérése, következtetések levonása, későbbi beépítése.

A fentieknek megfelelően tehát már a tervezéskor megkezdődik a partnerség érvényesítése, akár az inputgyüjtést, akár pl. a dokumentumok egyeztetését említve. 
A cél az, hogy eljussanak az érintettekhez, az érdeklödökhöz, azok kifejthessék véleményüket, amelyek optimális esetben minél nagyobb arányban találkoznak a tervezök elgondolásaival, és a lehető legtöbb esetben figyelembe vehetők. A gyakorlatban természetesen el térô a társadalom aktivitása, és sok múlik azon is, hogy az egyeztetéseket mennyire jól szervezetten hajtják végre. Ehhez szükséges elözetes koncepció, megfelelö ütemezés, határidök, „,helyes”, akceptálható módszerek alkalmazása. Kiemelendö, hogy a szélesebb közönség elérése és az egyszerüsítés érdekében célszerü az anyagokat interneten közzétenni, itt hozzászólási lehetöséget biztosítani.

1999-ben az EB számára jelentés kés zült a partnerségrool. ez az alábbiakat említi a partnerség elönyeként (Pálné Kovvács l. 2004):

- a folyamatok nagyobb átláthatósága, legitimitása. fokozottabb elkötelezettség az Alapok iránt,

- a programozás, projektszelekció, monitoring nagyobb hatékonysága,

- lehetőség a tanulásra, innovációra a szervezeti határok átlépésével,

- intézmények kapacitásfejlesztése.

Az elv megvalósítása eltérỏ országonként, döntési szintenként, programonként, szakaszonként. Legelterjedtebb a tervezésben és projektszelekcióban, változó a különbözö operatív teendőkben, és hátrébb szorul a monitoringban, értékelésben. Összességében azonban elmondható, hogy a partnerség komolyan beépült a nemzeti intézményrendszerekbe.

Mint látható, a partnerség témaköre kiterjedtségénél fogva meglehetősen tág, de a tanulmány célja kifejezetten a 2007-2013-as időszakra vonatkozó második Nemzeti Fejlesztési Terv (NFT) megalapozásához kapcsolódó, elkészült tervdokumentumok - Országos Fejlesztéspolitikai Koncepció (OFK), Országos Területfejlesztési Koncepció (OTK) - társadalmi egyeztetésének körüljárása. ${ }^{2}$

\section{Partnerség Magyarországon az NFT, OFK, OTK tervezésében}

Magyarországon a partnerség elve a területfejlesztésben már jóval az uniós csatlakozás elött megjelent. Az 1996-os területfejlesztési törvény elöírja, hogy a feladatokat az állami szervek, önkormányzatok, természetes személyek és szervezeteik, a gazdálkodó és érdekvédelmi szervezetek, valamint más intézmények összehangoltan, egymással együttmüködve látják el. Az 184/1996 Korm. rendelet tartalmazza a területfejlesztési koncepciók és programok egyeztetésének rendjét, melyben meghatározzák a dokumentumokat véleményező kört, a válaszadásra rendelkezésre álló idő minimumát. Ennél részletesebb elöírások egyik jogszabályban sem találhatók, de ebböl önmagában nem következtethetünk arra, hogy az alkalmazott gyakorlat megfelel-e a különböző szereplök igényeinek.

Az említett jogszabályok hatálya azonban a tárgyalandó tervek közül csak az OTK-ra terjed ki, azok nem vonatkoznak az NFT-re, az Operatív Programokra (OP), az OFK-ra stb. - ez utóbbiak szabályozása eddig kormányhatározatokban történt. Ezért is olvasható a szakirodalomban egy olyan tervtörvény megalkotásának 
a szükségessége, ami valamennyi fejlesztési tervre irányadó, és az összes fontos kérdést (beleértve a partnerséget) szabályozza. (Ám erre egyelöre nem látszik kormányzati szándék.) Ez persze nem jelentene teljes garanciát arra nézve, hogy az egyeztetések mindig a kívánatosnak megfelelöen történjenek, de a jelenlegi ad hoc, jogi keretek nélküli módszerekhez képest mindenképpen elörelépés lenne.

\section{Az elsö Nemzeti Fejlesztési Terv}

Az összehasonlítást megkönnyítendö, praktikus elöbb azt megnézni, hogyan alakult a partnerség a 2004-2006-os idöszakhoz kötődö 1. NFT esetében, mivel az ennek kapcsán megfogalmazott tapasztalatok döntők lehetnek a későbbi tervegyeztetésben. Azonban figyelembe kell venni néhány olyan körülményt, ami legalábbis részben magyarázatot ad azokra a kritikákra. amelyeknek utóbb a szakemberek hangot adtak. Természetesen ezek nem mindegyike van összefüggésben a partnerséggel, de közvetetten mégis befolyásolták azt.

- Az újonnan csatlakozott (2001-2002-ben csatlakozni vágyó) EU tagállamoknak nem álltak rendelkezésre tapasztalatok a fejlesztési dokumentumok elkészitésével, egyeztetésével (végrehajtásával) kapcsolatban.

- Mivel 2002 tavaszán új kormány került hatalomra, annak kb. egy éve volt a tervezési munkálatok elvégzésére, ami túlzottan szúkös időkorlátokat eredményezett. (Az új kormány csak a helyzetértékelést vehette át az előzőtől, de ezt is aktualizálni kellett.)

- Tekintve, hogy a politikai oldalak között nem volt konszenzus az I. NFT alapvetö kérdéseiben, illetve az egyes kormányok „saját ciklusuk” közben sem dolgozták ki a maguk közép-hosszú távú ágazati stratégiáit, nem lehetett korábbi anyagokra támaszkodni, azokat beépíteni.

- Maga a (terület)fejlesztési intézményrendszer sem volt „bejáratott”, egyes hivatalok felállítása (Nemzeti Fejlesztési Hivatal (NFH), Országos Területfejlesztési Hivatal $(\mathrm{OTH})$ ) a régiókban pedig ugyan már korábban is müködtek a Fejlesztési Tanácsok (RFT), Ügynökségek (RFÜ), ${ }^{3}$ azok addigi tevékenysége, kapacitásai nem voltak elégségesek ahhoz, hogy stabil, kompetens partnerként vehessenek részt a tervezésben.

Az NFT melléklete meglehetösen részletes tájékoztatást ad az egyeztetési folyamatról. Ebböl az derül ki, hogy a dokumentum elkészítésének felelősei elvben igen nagy hangsúlyt fektettek erre, az már más kérdés, hogy a partnerek hogyan látták a realizálást, illetve itt kell megjegyezni azt is, hogy a véleményezési jog nem jelenti azt, hogy a tervezöknek a javaslatokat kötelezöen el kell fogadniuk. Ök nyilvánvalóan szelektálni fognak aszerint, hogy az adott elem mennyire illeszkedik a célokhoz, a többi részlethez. Tehát a különböző szereplök kifogásai közül azok tekinthetök elsősorban indokoltnak, amik elvi, módszertani jellegúek (ezekröl később). 
A partnerek megkeresése - szociális, gazdasági, szakmai, regionális ${ }^{4}$, civil, kisebbségi és női szervezetek, önkormányzati érdekszövetségek - három szakaszra tagolódott: elöször a helyzetfelmérést és a stratégiát, azután az operatív programokat, majd a teljes dokumentumot megvitatták. Az egyeztetésnek többféle módszere volt:

- A Miniszterelnöki Hivatal Nemzeti Fejlesztési Terv és EU Támogatások Hivatala (NFTH) ${ }^{5}$ együttmüködési megállapodást kötött néhány kiemelt partnerrel - mint pl. a Magyar Kereskedelmi és Iparkamara, a munkavállalói oldalt képviselö hat országos szakszervezeti szövetség, a kilenc országos munkaadói szövetség, a Magyar Agrárkamara, a Települési Önkormányzatok Országos Szövetsége -, ennek értelmében a felek együttműködnek az NFT elkészítése, végrehajtása, értékelése és ellenőrzése során, a kölcsönös tájékoztatás, oktatás, képzés, társadalmi egyeztetés terén.

- A Hivatal közvetlen megkereséssel fordult több mint 600 szervezethez (levélben vagy e-mailben), $k b .350$ válasz érkezett.

- A személyes kommunikáció keretében az NFT-ért és az OP-kért felelös miniszter és a regionális szereplök (RFÜ-k) konzultációkat tartottak, információkat adtak az NFT-vel kapcsolatos feladatokról, a Hivatal önálló fórumokat, rendezvényeket szervezett.

- A dokumentum végleges változatát magtárgyalta több makroszintü és regionális partner (Országos Területfejlesztési Tanács, Országos Érdekegyeztető Tanács, Országos Környezetvédelmi Tanács, Országos Cigányügyi Tanács, Regionális Fejlesztési Tanácsok).

- Interneten keresztül letölthetők voltak az egyeztetésre szánt anyagok, illetve hozzá lehetett szólni, módosító javaslatokat lehetett tenni az egyes témákhoz.

- A Regionális Operatív Program (ROP) elkészítéséért és vitára bocsátásáért az NFTH felelt, a tervezés feladlata azonban a VÁTI Kht.-ra hárult, illetve bevonták az ügynökségeket is. A részanyagokat a regionális munkacsoportok ülésein megtárgyalták a régiók és az ágazati minisztériumok képviselöi - a régión belüli konzultációért elsösorban az RFÜ-k feleltek. A folyamat itt is három szakaszra bomlott: elöször a helyzetelemzést, késóbb a stratégiát, majd a teljes operatív programot megvitatták.

A melléklet számos statisztikát közöl a folyamat eredményéröl, pl. a válaszadók státus szerinti, ágazati, területi stb. megoszlásáról, a javasolt prioritásokról, összefoglalja az egyes csoportok véleményét.

Ami a partnerek szemszögét illeti, nem áll rendelkezésre az egyes szereplők tapasztalatait teljeskörüen feltáró anyag, de Márton (2004) tanulmánya számos tanulságra felhívta a figyelmet (elsősorban a régiók szemszögéböl).

- A szükös időkeretek miatt a konzultációk dömpingszerün alakultak, ami nem tette lehetôvé a tervezési folyamat megfelelö követését, nem hagyott elég időt a javaslatok érdemi kidolgozására, a visszacsatolásra. 
Molnár Beáta : Partnerség a magyar fejlesztési koncepciók tervezésében.

Tér és Társadalom 20. évf. 2006/3. 79-93. p.

- Az átláthatóságot rontotta a kormányhatározatban való szabályozás is, ami lényegében csak a határidőket és a felelős államigazgatási szervek körét tartalmazta - ezáltal a kompetenciaviszonyok sem voltak világosak.

- Mivel a dokumentumok folyamatosan változtak, nem volt stabil tárgya az egyeztetésnek, ami nehezítette a véleményalkotást - ugyanakkor elmaradt a konzultáció a véglegesített operatív programokról.

- A helyi partnerek közül a civil szervezetek, a vállalkozók és a politikai elit képviselöi is többnyire távol tartottík magukat az egyeztetéstöl, így sajátos érdekeiket sem tudták megjeleníteni.

- A regionális szereplök gyengeségeként (is) értékeli azt is, hogy végül egyetlen ROP született, ráadásul tematikus prioritásokkal, ${ }^{6}$ illetve a régiós szakemberek részvételét egyetlen alsó szintü munkacsoport bizısította a tervezésben, a koordinációs bizottságban már csak a TERET ${ }^{7}$ kapott tanácskozási jogot.

A szerző szerint egyrészt fokozottabban kellene törekedni a fenti kimaradók bevonására, másrészt konkrét javaslatot is tesz a folyamat jobb, hatékonyabb megszervezésére.

Igaz, ez „csak” egyetlen vélemény, de más anyagokban található részletek, valamint egyéb információk alapján úgy tünik, ezek tipikus és vélhetően mások által is osztott problémák. A kérdés az, hogy ezek a meglátások találkoznak-e a kormányzati szereplök véleményével, és ennek tükrében várható-e változás a késöbbi egyeztetések során.

\section{OFK, OTK, 2. NFT}

Bevezetésképpen meg kell jegyezni, hogy mivel Magyarország csak 2004 közepén csatlakozott az EU-hoz, a következö programozási periódus pedig 2007-től kezdődik. és a dokumentumokat (Nemzeti Stratégiai Referenciakeret (NSRK=NFT, OP-k) 2006 folyamán át kell adni az EB-nek, valójában már jóformán az 1. NFT indulásától elö kellett (volna) készíteni a 2007-2013-as ciklushoz kötödő feladatokat.

- Értékelni kell az 1. NFT megvalósulását intézményi, pénzügyi, eredményességi stb. szempontból, ennek alapján lehet javaslatokat tenni az esetleges módosításokra.

- Mivel korábban elmaradt az Átfogó Fejlesztési Terv kidolgozása, össze kellett állítani egy olyan koncepciót (ez lett az Országos Fejlesztéspolitikai Koncepció), ami tágabb a második Nemzeti Fejlesztési Tervnél, kiterjed a hazai finanszírozású fejleszlésekre is, és hosszabb időszakra tekint ki. Ez nem kötelezö, de praktikus, és volt is rá szándék, ami 2002-vel ellentétben most realizálódott.

- Az előzöhöz kapcsolódóan nem csak a fejlesztési elképzelések (célok, prioritások) kialakításáról van szó, hanem az intézményi keretek esetleges megváltoztatásáról, decentralizálásáról is. 
- Idószerü volt az Országos Területfejlesztési Koncepció hatévenkénti felülvizsgálata, amit értelemszerüen a többi dokumentummal összhangban célszerü megtenni.

- Felmerült, hogy az NFT szabályozása ne kormányhatározatokban történjen, ezért ki kell találni a jogi keretekre vonatkozó optimális megoldást.

- Végül sort kell keríteni maguknak a terveknek (NSRK, OP-k) az összeállítására.

Minderre a rendelkezésre álló (hátralévő) idő ismét szükös, ami felveti azt az aggályt, hogy bizonyos hibákat nem sikerül kiküszöbölni.

A fenti pontok mindegyike érinti a partnerséget, ezért röviden érdemes áttekinteni, mi történt eddig.

Még 2004-ben elfogadták az 1076/2004 Korm. határozatot az Európa-terv kidolgozásának tartalmi és szervezeti kereteiröl. Ennek legfontosabb elemei témánk szempontjából az alábbiak:

- El kell készíteni az OFK-t és vele párhuzamosan a megújított OTK-t. Az OFK egy hosszabb távú, 2020-ig kitekintő, uniós és hazai forrásból megvalósuló fejlesztésekre irányadó dokumentum, az OTK gyakorlatilag ennek a területi metszete. E két koncepció alapját képezi a későbbi tervezésnek, őket a parlament elé kell terjeszteni.

- A határozat deklarálja a régiók ágazatokkal egyenlő súlyát a tervezésben. A tematikus munkacsoportok mellett a régiókban az RFÜ-k bázisán regionális munkacsoportok jönnek létre, amelyek bevonják a szakmai, ágazati, gazdasági, szociális partnereket, illetve a tudomány képviselöit.

A fentiekkel összhangban 2005-re valóban elkészült az OFK és az OTK, ezek társadalmi egyeztetése a nyáron zajlott, a parlament elé novemberben kerültek, elfogadásuk az eredetileg tervezett március helyett ${ }^{8}$ az év végén történt meg. ${ }^{9}$ Folyamatban van az Nemzeti Stratégiai Referenciakeret és az operatív programok kialakítása, de ezekről nyilvános munkaanyagok még nem ismertek. Az eredeti elgondolás szerint (NFH) az NSRK elkészítésének határideje 2005 vége, az OP-k esetében 2006 január-március volt, ezt azóta már kitolták (erról később). Várhatóan nem lesz változás abban, hogy a programokat továbbra sem viszik a parlament elé, ez nem is elóírás, de többek szerint nagyobb legitimitást biztosítana.

A tervezés szakaszában a partnerségre vonatkozóan az alábbi elemekböl indulhatunk ki. Egyrészt az NFH honlapján a partnerségi oldalakon ${ }^{10}$ szerepelnek az elvek, és itt találhatók különböző anyagok (OFK, OTK ${ }^{11}$ ) is. Másrészt az EU Füzet (NFH [3], 2005) leírja a társadalmi-gazdasági együttmüködés rendjét, ami táblázatos formában tartalmazza az egyeztetés ütem- és feladattervét - ez utóbbi az OFK-ra (vele együtt mozog az OTK), NSRK-ra és az OP-kra vonatkozik. Elkülönítik a folyamat egyes szakaszait, meghatározzák a partnerek körét, a részvétel módját és a határidöket. 
Molnár Beáta : Partnerség a magyar fejlesztési koncepciók tervezésében.

Tér és Társadalom 20. évf. 2006/3. 79-93. p.

A civil részvétel rendszere:

- információkhoz való hozzáférés: a tervdokumentumok olvashatók az NFH honlapján,

- aktív tájékoztatás: a tervezésben részt vevő állami szervek tájékoztatják a társadalmat a tervezỏmunka menetéről (sajtó, internet, egyéb formában),

- széleskörủ társadalmi konzultáció: minden érdeklődő kifejtheti a véleményét írásban és szóban (nyilvános fórumok), az NFH internetes fórumot múködtet,

- közvetlen részvétel: a tematikus és regionális csoportok a folyamat egészében jelen vannak, így a partnerek bevonásán keresztül biztosított a civil részvétel,

- civil egyeztetés partnereinek kiválasztása: a társadalmi érdekcsoportokat reprezentáló szereplők kiválasztása, ezekkel együttmüködés - a munkacsoportok önállóan döntenek a partnerekröl.

A sikeres társadalmi egyeztetés alapelvei (részben eltér a korábbiaktól):

- strukturáltság: a kormány nyilvánosságra hozza a tervezés folyamatát, menetrendjét, a civil szervezetek részt vehetnek a munkacsoportokban

- részvétel: a civil szervezetek megismerhetik és véleményezhetik a dokumentumokat

- folyamatosság: a kapcsolattartás folyamatos a civil szervezetekkel, azok a tervezés valamennyi szakaszában jelen vannak

- nyitottság, nyilvánosság: az egyeztetési folyamat nyitott, átlátható, befolyásolható, az államigazgatási szereplők rendszeresen információt nyújtanak, a kapcsolattartást dokumentálják, a felvetésekre válaszolnak

- visszacsatolás, értékelés: a kormányzat jelentést készít az egyeztetésröl, a vélemények beépítéséröl.

A fentiekböl látható, hogy az elkötelezettség megvan a partnerségi elv eröteljes érvényesítésére, de kérdés, hogy a gyakorlat összhangba kerül-e ezzel a szándékkal. Ugyanakkor ezek a deklarációk arról semmit sem mondanak, hogy az egyeztetés hatékonyságát és eredményességét milyen tényezők garantálják, és a fó problémák általában inkább ebböl származnak. Nem véletlenül kérik számon sokan egyrészt a társadalmi viták forgatókönyvének részletes kidolgozását és közzétételét, másrészt a törvényi megoldást. Mindamellett a Hivatal jogosan kéri azt, hogy a partnerek is cselekedjenek felelősen, és előre szervezzék meg saját részvételük módját. Ahogy azt is leszögezi, hogy a partnerek joga a vélemény nyilvánítás, a javaslatokról a döntés a kormányzat joga és felelössége.

Az EU Füzet összefoglaló táblázatból pedig az derül ki, hogy az elkülönített hét szakasz (első a helyzetértékelés, inputgyüjtés, utolsó az operatív programok véleményezése) mindegyikében szerepet kapnak a kiemelt partnerek és a társadalmi nyilvánosság is. A részvétel módja a két körnél részben eltérö: míg az inputgyüjtésnél a kiemelt partnerek esetében a bevonás formája a mühelymegheszélés, a többi 
csoportnál a regionális fórum (RFÜ-k szervezésében), addig a véleményezésnél a kiemelt partnerek írásban adnak választ (a módszer közelebbről nem definiált), a szélesebb közvélemény pedig internetes fórumhoz csatlakozhat. Az időkeret teljes folyamata kb. egy év, 2005 első negyedévétől 2006 januárig tart (ez mint történt rá utalás, csúszik mind a koncepciókat, mind az NSRK-t és az OP-kat illetően).

Az alábbiakban azt nézzük meg, hogyan zajlott az egyeztetés eddig a gyakorlatban.

Első szakasz ${ }^{12}$ : Az OFK (NFT) kidolgozásának folyamata egészen 2004 elejéig nyúlik vissza, február 23. és június 21. között az NFH 17 alkalommal szervezett háttérbeszélgetéseket a fejlesztéspolitikai célokról. Ezeken általában néhány (2-6) ember vett részt, akik a tervezés szempontjából jelentősnek ítélt intézményeket (egyetemek, kutatóintézetek, magáncégek) képviseltek. A résztvevők (összesen több mint 60 ember) névsora és a beszélgetések átiratai megtalálhatók a Hivatal honlapján.

Az NFH által regisztrált ún. jövőképviták (közel 50, az írásos anyagok hozzáférhetők) valamivel később, 2004 november elején kezdődtek, és 2005 április elejéig tartottak. Ezeket a tematikus munkacsoportok tevékenységi köre alapján strukturálták, egy-egy rendezvényre - amelynek társszervezője általában valamelyik folyóirat volt - itt is néhány (3-9) embert hívtak meg. A résztvevők köre szervezeti szempontból az elözőhöz hasonlóan alakult, amennyiben a leginkább érintett intézmények képviselöi (elsősorban a tudományos szférából) kaptak meghívást (összesen 100-150 fö). Az ilyesfajta szelekciónál kérdésként merülhet fel, hogy valóban az adott témában legjáratosabb, legilletékesebb szereplőket választják-e ki, de ez kívülről az információk teljességének birtoklása nélkül nehezen eldönthetö. Maga a megoldás ugyanakkor elvben nem vitatható.

Az NFH összefoglalja azokat a rendezvényeket is, amelyekre 2005. február elejétől július közepéig került sor, azaz az OFK előzetes munkaanyagának elkészültétől a hivatalos társadalmi egyeztetésre bocsátás időpontjáig. Ezek lényegében a hivatali (NFH, OTH) szakértök által tartott előadások voltak (kb. 80) a legkülönfélébb alkalmakkor (roadshow-k, egyebek).

A helyszíneket tekintve a jövőképvitákat általában Budapesten szervezték, vidéki városokban kevesebbszer, és azok sem „fedték le” az ország összes régióját, megyéit, nagyobb városait. A többségében roadshow-kon megtartott elöadások már területileg jóval nagyobb kört alkottak, azonban a jelentősebb városokon túl ezek sem terjedtek, miközben egy-egy helyszínre (pl. Szeged, Pécs, Debrecen) többször is visszatértek.

Az NSRK megalapozása érdekében a tárcák mühelyvitákat szerveztek (13 szakterületi bontásban), ezekben alkalmanként 20-30 ember vett részt. ${ }^{13}$

Második szakasz: Az Országos Fejlesztéspolitikai Koncepciót (Országos Területfejlesztési Koncepciót) végül 2005 júniusában hozták nyilvánosságra, a dokumentumokat feltették az internetre, az Nemzeti Fejlesztési Hivatal (Országos Területfejlesztési Hivatal) honlapjára. Az OFK két részböl áll (helyzetelemzés, célok és eszközök), valamint van még egy összefoglaló kiadvány is. Az egyeztetés nyár végén zárult le - a válaszadás elektronikus formában történt a könnyebb feldolgozhatóság miatt -, ezzel összefüggésben az NFH jelentést tett közzé. Ebböl, illetve a kérdöíves 
Molnár Beáta : Partnerség a magyar fejlesztési koncepciók tervezésében.

Tér és Társadalom 20. évf. 2006/3. 79-93. p.

válaszok összegzö anyagából (NFH (1) (2), 2005) többek között az alábbiak derülnek ki, kiegészítve saját véleménnyel:

- Az OFK-t közel 9 ezren töltötték le az internetrỏl, itt közvéleménykutatást is rendeztek a specifikus célok elfogadottságáról, amiben 2730-an vettek részt. (Hogy ez sok vagy kevés, azt önmagában, összehasonlító elemzés nélkül nem egyszerú minösíteni.)

- A véleményezésre a Hivatal strukturált elektronikus formát választott a rövid feldolgozási időre tekintettel, ennek keretében július elején CD-n kétezer szervezetnek küldte meg az OFK-t, OTK-t és a használandó kérdőíveket. A válaszadásra augusztus közepéig volt idő, de a kérdöíveken túl számos írásos javaslat is érkezett. Összesen mintegy 350 szervezet küldte meg a véleményét (ebböl kb. 300 kérdőív és 50 szöveges értékelés), ami 17-18\%-os arányt jelent (a legaktívabbak a regionális, egészségügyi, oktatási-tudományos és környezetvédelmi szervezetek voltak). Ez az arány a körülményekhez képest - az anyagok „házhoz mentek”, szervezetekhez és nem magánszemélyekhez - szerénynek mondható, és ennek fényében elgondolkodtató, hogy a civil társadalom egészében vajon mennyi igény van arra, hogy beleszóljon az ország jövőjét érintő ủgyekbe. Miközben persze a másik oldalon, az aktív kisebbség részéröl határozott elvárások fogalmazódnak meg a részvétel intenzitását, módszerét és egyebeket illetően.

- A jelentés leírja, hogy az egyes célokat mennyiben, milyen sorrendben támogatták a partnerek, illetve milyen javaslatokat tettek a gazdaság, a társadalmi célok és a fenntarthatóság, területi és társadalmi kohézió, decentralizáció vonatkozásában (OFK). Ugyanakkor, ahogy a Hivatal is elismeri, az OFK-val kapcsolatban éppen az volt a legföbb kritika, hogy túlságosan átfogó ahelyett, hogy hangsúlyokat jelölne ki, és ebböl következöen a kérdésekre adott válaszokból sem vonhatók le messzemenő következtetések. Ugyanis nem meglepö, hogy a partnerek egyetértenek, pl. a versenyképes Magyarország megteremtésével, a népesség egészségügyi állapotának javításával, a foglalkoztatás bỏvítésével vagy a versenyképes tudás növelésével. $\mathrm{Az}$ érdekes ebben maximum a sorrend kialakítása lehet, de nincs információ arról, hogy ha a célok megvalósítása számos okból korlátozott - márpedig nyilván az még középtávon is -, akkor a szervezetek mihez ragaszkodnának mindenképp, miröl mondanának le, illetve egyáltalán mit gondolnak reális és kívánatos jövöképnek, milyen eszközöket alkalmaznának a célok elérése érdekében. Vagyis nem derül ki, hogy a vonzó, de kevésbé hitelesnek tünó kívánságlista milyen szükebbre szabott és racionálisabb egyéni koncepciókra .váltható át”. Ráadásul az egyes célok mellett feltüntetett javaslatok semmi olyasmit nem tartalmaznak, amit bárki ne sorolt volna fel, ha megkérdezik, de ettöl nem kerülünk közelebb a végrehajthatósághoz. Hozzá kell tenni, hogy mindez legalább annyira a véleményezés módszertani hibája, mint az OFK hiányossága. Mindamellett a Hivatal védelmében azt is le kell szögezni, hogy 
a prioritások kijelölése nehéz és konfliktusgerjesztỏ lépés, ez esetben valószínüleg az lenne a reklamáció tárgya, hogy valamely terület miért maradt ki.

- Ami a koncepciókban megjelenő intézményi kérdéseket illeti, a jelentés tanúsága szerint a véleményezők hiányolják a (közelebbről szintén nem körülírt) közigazgatási reformot, a regionalizmust, a decentralizációt.

- Nem szükséges részletesebben ismertetni, hogyan dolgozták fel - háromszor is - a beérkezett válaszokat (tartalomelemzés, program segítségével kulcsszavak keresése, gyakoriságmérés), az viszont érdekes, hogy mennyire vették figyelembe a véleményeket. Ez azonban a jelentésböl nem derül ki pontosan, csak annyi tudható, hogy a beépíthetöséget a tárcák vizsgálták, de a döntést az FKTB TOB ${ }^{14}$ hozta meg augusztus végén. A több mint száz módosító javaslat nagyobbik részét a testïlet akceptálta. (Az NFH megőrizte a fel nem használt véleményeket is, esetleges késöbbi beépíthetöség okán.)

- Annak elemzése, hogy végül mennyiben változott az eredeti munkaanyag, túlmutat a cikk keretein, de a legfontosabb megállapítást azért meg kell tenni. Látható, hogy a tervezök egyes részeket (szavakat, mondatokat, egész bekezdéseket) kihúztak, másokat helyettük beillesztettek, illetve teljesen új tartalmak is bekerültek az anyagba. Ugyanakkor ezeknek a módosításoknak a nagyobb része inkább átfogalmazásnak, apróbb pontosításnak, kiegészítésnek tekinthetö, nem érdemi változtatásnak. Talán a környezeti szempontok fokozottabb figyelembevétele az, ami az új OFK-ban jól érzékelhetöen nagyobb hangsúlyt kapott az egyeztetést követően.

- A visszacsatolás azt jelenti, hogy a résztvevő szervezetek írásban választ kapnak véleményeik sorsáról - ezt a szándékot az NFH megerösítette, de jelezte, hogy a folyamat hosszabb időt vesz igénybe.

Az OTH kifejezetten az OTK egyeztetéséröl ilyen összefoglaló anyagot nem hozott nyilvánosságra, csak az érintett hivatali szakemberek álláspontjára lehet hivatkozni, amiböl az derül ki, hogy az OTK céljainak elfogadottsága igen magas ( $80 \%$ feletti) volt, és a javaslatok nagyobb hányadát integrálni is tudták.

Arról, hogy a tágabban értelmezett társadalom, illetve a magát érintettnek gondoló (aktív) civil szféra hogyan értékeli a partnerség eddigi megvalósulását, nem is lehet teljeskörú információnk, a hozzávetöleges képalkotáshoz is közvéleménykutatás szükséges. Azonban a tájékozódást segíti, hogy magalakult egy olyan akciócsoport - Civilek a Nemzeti Fejlesztési Terv Nyilvánosságáért (CNNy) -, ami magára vállalta, hogy nyomon követi és elemzi az NFT egyeztetésének folyamatát, és javaslatokat tesz a tapasztalt problémák kiküszöbölésére a partnerség javítása érdekében. A CNNy negyedévente jelentést készít, amelyek felkerülnek a saját honlapra. Az alábbiakban a szervezet fỏbb észrevételei, kritikái, javaslatai olvashatók ( $C N N y$ 2005) (amelyekkel túlnyomórészt egyet lehet érteni), kiegészítve saját véleménnyel:

- Korábban (első jelentés) a CNNy komolyan kifogásolta a társadalmi egyeztetés állandó csúszását, az információk hiányát. Ehhez képest jelentös elöre- 
lépéseket tapasztalt több tekintetben, de a későbbi időszakra vonatkozóan (második jelentés) is számos kritikát fogalmazott meg.

- Általános problémaként említette egy olyan komplex egyeztetési terv hiányát, ami részletesen tartalmazná a tervezési folyamat fázisait, a határidöket, módszereket, a civilek teendőit, a kontaktszemélyek elérhetőségét.

- A határidőket illetóen a szervezet azt gondolja, hogy az egyes dokumentumok súlyának megfelelö, elégséges idökeretet biztosítani kell, ami eddig nem történt meg. Az OFK-t (OTK-t) elvileg több mint három hét alatt kellett véleményezni, de ezt több tényezö is nehezítette. Egyrészt a július 20augusztus 13. közti időszak a nyári szabadságolások ideje, ami fỏleg kisebb szervezeteknél okoz gondot. Másrészt az eredeti határidő augusztus vége volt, és ezután következett be az előre nem látható, civilek számára hátrányos módosítás a dátum előrehozásáról. Harmadrészt a kereteket tovább feszítették a technikai problémák, amelyek az egyébként helyesnek vélt elektronikus formából adódtak. Ugyanis a kérdőívek kitöltéséhez, megnyitásához szükséges programot nem tudták használni a korábbi verziókkal rendelkező partnerek. Mire a mindenki számára alkalmazható változatot feltették az internetre, már augusztus eleje volt.

- A strukturált kérdőíves megoldást a CNNy a könnyebb feldolgozhatóság szempontjából pozitívan értékeli, de ennek a formának a túlsúlyos alkalmazását hátrányosnak tartja, mivel szủkíti a válaszolás mozgásterét, így valójában nem derülhet ki a partnerek álláspontja. A kérdóív eleve nem tud minden területet átfogni (ami kimarad, azt nem lehet véleményezni), és kiindulási alapnak tekinti a stratégiai célok helyességét.

- A szervezet szerint a civileket már a tervezés kezdetekor be kell vonni, és arra is lehetöséget kell biztosítani, hogy magát az egyeztetési folyamatot, a kérdóívek módszertanát bírálják, javaslatot tegyenek.

- Szintén kifogásolják, hogy a beérkezett vélemények feldolgozásába nem tekinthettek bele, csak vázlatos információkat kaptak ennek módszereiról, igy nem látják annak a garanciáit, hogy a válaszokat „,helyesen” értékelték-e. Ezen kívül nem vehettek részt a módosítások beépíthetőségérỏl tárgyaló Tervezési Operatív Bizottság ülésein sem, holott az indoklás a nyilvánosságra tartozik. Ami a visszacsatolást illeti, a beküldéstól számított egy hónap múlva még mindig nem jött visszajelzés az NFH-tól - az államigazgatási határidók tartását minden esetben kérik a hivataloktól.

- A CNNy örvendetesnek ítéli az internetes kommunikációt, több honlapot megvizsgált. Jogos észrevételként vetette fel (bár bizonyos elemekben történt változás), hogy az NFH honlapján viszonylag nehezen találták meg az elérni kívánt anyagokat, információkat. Ugyanis nem evidens, hogy a fejlesztési dokumentumokat a „Partnerség” címszó alatt keressük, ami ráadásul nem is szerepel az oldalmenüben. A legkézenfekvőbb megoldásként értékelhető „Tervezésre” kattintva az 1. NFT anyagaihoz jutottunk. Az egyik partnerségi 
oldalon szerepel tehát az OFK és az OTK, de előfordultak olyan kellemetlenségek, hogy két dokumentum össze volt cserélve, illetve a borítón látható dátum nem egyezett meg a láblécen jelzettel, így nem volt világos, melyik változatot olvassuk. A fentieket kiküszöbölve praktikus lenne olyan dokumentumtárat létrehozni, ami jól strukturáltan tartal mazná az összes anyagot. Hozzátéve, hogy az aktualizált verziókat minél hamarabb kívánatos feltenni. (Szintén nem ártana a jogszabályokat is egyszerübben fellelhetö helyen gyủjteni.) Lényeges lenne az eseménynaptár naprakész, teljeskörủ nyilvántartása. A Fejlesztéspolitikai Portál ugyan elvileg feltehetően azt a célt szolgálja, hogy valamennyi információ átlátható formában jelenjen meg, ez a gyakorlatban nem így van, egyes dokumentumok vagy egyáltalán nincsenek ott vagy már elavult változataik érhetök el. Mindemellett azt is érdemes figyelembe venni, hogy bár az Internet kétségtelenül jó megoldás azok számára, akik érdeklödnek, technikailag képzettek és rendelkeznek hozzáféréssel, mások szempontjából (akikre az előbbiek nem teljesülnek) ez nem kielégítö. Ha tehát a hivatalok valóban mindenkihez el akarnak jutni, beleszólást akarnak engedni, akkor más formában (szórólap, kiadvány, tévé, sajtóhirdetés stb.) is intenzívebben kellene kommunikálni.

- Tanulságos még a jelentésben egy táblázat, ami többek között a Regionális Civil Fórumok (RCF) és a nyilvánosság részvételét vizsgálja a tervezésben. Ebböl az derül ki, hogy egyedül a Közép-magyarországi és a Dél-dunántúli régióban valósul meg viszonylag nagyobb mértékben a partnerség, itt az RCF jelen van az Regionális Fejlesztési Tanács ülésein, igaz, véleményét sokszor nem építik be, hozzájárult a 2007-2013-as tervek kidolgozásához és a szélesebb nyilvánossággal együtt véleményezte azt. A tơbbi térségben a kép vegyesebb, több a nemleges válasz és az adathiány (Észak-Alföldről egyáltalán nincs információ).

\section{Értékelés és összegzés}

A leírtakból az a következtetés vonható le, hogy Magyarországon a partnerségi elv megfelelö alkalmazására a hivatali szervek részéröl van hajlandóság. a civil szféra részéröl pedig igény, ugyanakkor a pozitív fejlemények mellett számos probléma is megfogalmazható.

A tervezési szakaszban - ellentétben a végrehajtással - jelentősebb mértékben részt vehetnek a legkülönfélébb intézmények, célul tüzhető ki a legtágabban értelmezett nyilvánosság. Ez természetesen szintén nem jelenti azt, hogy a részvétel módja vagy a befolyásolás lehetősége korlátlan, keretek nélküli lenne, ezt is különbözö elvárások összeegyeztetésével kell kialakítani, a folyamat eredményessége a kormányt kötelezi. Ugyanakkor egyes elemekben - pl. anyagok olvashatósága, internetes fórumon hozzászólás - a civilek sokasága megjelenésének nincs akadálya, még akkor sem, ha egy részük valószínủleg nem nevezhető kompetensnek. A tervezéssel kapcsolatban - kiknek jut szerep a kidolgozásban, munkacsoportok, 
megismerhetöség, véleményezés, igények beépítése - a leírtak alapján az a konklúzió, hogy miközben a hivatalok egyfelól eleget tettek a partnerség követelményének, még számos dologban keresni és alkalmazni kell az eddiginél jobb megoldásokat (pl. határidók, technikai feltételek stb. tárgyában).

\section{Jegyzetek}

1 Az uniós pénzeszközök csak kiegészítik a hazai forrásokat.

${ }^{2}$ A hivatkozott 1260/1999 EK rendelet elóírja, hogy az uniós források megszerzéséhez fejlesztési tervet és operatív programokat kell készíteni. Az ezek megalapozását szolgáló hosszútávú koncepciók kidolgozása nem kötelezö, de saját érdekünkben praktikus.

3 Felállításukat a Tft. 1999-es módosítása tette kötelezỏvé, az ügynökségek a fejlesztési tanácsok munkaszervezetei. Regionális szinten az RFT-k a területfejlesztés letéteményesei, felelnek a tervek elkészítéséért, a rájuk bizott hazai források elosztásért.

${ }^{4}$ Regionális és megyei fejlesztési tanácsok, megyei közgyúlések, kistérségi társulások, telepuilési ònkormányzatok, dekoncentrált és civil szerve(zete) $k$.

${ }^{5}$ Jogelödje a 2004. jan. l-től létrehozott Nemzeti Fejlesztési Hivatalnak - mindkét hivatalt az uniós ügyekért felelös miniszter felügyelte.

${ }^{6}$ Ez azt jelenti, hogy a célok megközelítése szektoriális jellegủ és nem az egyes térségek sajátos szempontjaiból indul ki, amit sokan nyilvánvalóan sérelmeznek.

${ }^{7}$ Területfejlesztési Régiók Egyeztetổ Tanácsa (RFT-k, RFÜ-k vezetőit tömöríti).

${ }^{8}$ Ezért még az OGY határozatok elfogadása előtt megkezdỏdtek az NSRK munkálatai, illetve készủilt még két dokumentum (Fenntartható Fejlödés Stratégiája, Lisszaboni Akcióprogram). A határozati javaslatokhoz számos módosító indítványt nyújtottak be kormányzati és ellenzéki oldalról egyaránt. Az alapállás azonban az volt, hogy míg a kormánypárti képviselők dicsérték az anyagokat, addig az ellenzék jóformán még vitára is alkalmatlannak lartotta.

${ }^{10}$ Kiindulópont: www.nfh.gov.hu/xindex $2 . h t m ? t=2 \& \mathrm{j}=5343$

$11 \mathrm{Ez}$ az OTH honlapján is fenn van.

12 Forrás: NFH

${ }^{13}$ A fejlesztéspolitikai portálon (www.fejlesztespolitika.gov.hu) szerepel a záróvita háttéranyaga.

${ }^{14}$ Fejlesztéspolitikai Koordinációs Tárcaközi Bizottság Tervezćsi Operatív Bizottság

${ }^{15}$ www.oth.gov.hu

\section{Irodalom}

CNNy (2005) Második jelentés a nemzeti stratégiai anyagok tervezésének nvilvánossaigáról. www.nfh.gov.hu/doc/partnerseg/cnnyjelentes2.pdf

1076/2004 Korm. hat. az Európa-terv tartalmi és szervezeti kereteiröl.

1260/1999 EK rendelet a strukturális alapok általános szabályozásáról.

184/1996 Korm. rendelet a területfejlesztési koncepciók és programok egyeztetésének és elfogadásának rendjéról.

1996. évi XXI. $t v$. a területfejlesztésröl és területrendezésról.

Horváth Gy. (2001) Regionális támogatások az Európai Unióban. Osiris Kiadó, Budapest.

Lados M.-Rechnitzer J. (2004) A teriileti stratégiáktól a monitoringig. Dialóg Campus Kiadó, Pécs.

Magyar Nemzeti Fejlesztési Terv. 2004-2006 / Melléklet: Partnerség www.nfh.gov.hu/doc/nft/letolt3/ tarsadalmi_partnerseg.pdf

Márton Gy. (2004) Az Elsó Magyar Nemzeti Fejleszlési Terv tervezési folyamatának tapasztalatai regionális szemszögböl. Falu Város Régió. 9. 32-45. o.

N. Tóth K. (2005) Felkészälés a strukırális alapok kezelésére / A partnérség elve (elöadás). VÁTI.

NFH (1) (2005) A társadalmi egyeztetésre kérdölven beérkezett válaszok érićkelése.

NFH (2) (2005) Az OFK társadalmi egyeztetésének tanulságai. 
NFH (3) (2005) EU Fïzet: Gondolkodjunk együtt Magyarország jövöjéröl! www.nfh.gov.hu/doc/kiadv/ eufuzet.pdf

Országos Fejlesztéspolitikai Koncepció II. rész: Célok és eszközök (2005). www.nfh.gov.hu/doc/ partnerseg/ofkmasodikresz0629_korr_kk.doc

Pálné Kovács I. (2004) A magyar kózigazgatási reformkoncepció és a területfejlesztés intézményrendszerének összehangolása. - EU-tamulmányok IV. - Inotai A. (szerk.) Nemzeti Fejlesztési Hivatal, Budapest. 267-328. 0 .

Winkler Gy. (2004) Gazdasági szereplök a területfejlesztésben, helyük a tervezett rendszerben. www.b-m.hu/ idea/tanulm.html

www.nfh.gov.hu/doc/doku/ifm_tanulmanyok/ifm\%202004/palne_k_i_palicaifm.pdf www.nfh.gov.hu/doc/partnerseg/az\%20ofk\%20tars\%20egy\%20es\%20tanulsagai.pdf www.nfh.gov.hu/doc/partnerseg/diagramos_szoveges_ertekeles_09_01.pdf www.nfh.gov.hu/xindex $2 . h t m ? t=2 \& \mathrm{i}=5343$ (NFH partnerségi oldal) 